\title{
Deltamethrin and Permethrin in the Liver and Heart of Wistar Rats Submitted to Oral Subchronic Exposure
}

\author{
Mônica A. T. Santos, ${ }^{a}$ Marili V. N. Rodrigues, ${ }^{*, b}$ Miguel A. Áreas ${ }^{c}$ and Felix G. R. Reyes ${ }^{a}$ \\ ${ }^{a}$ Departamento de Ciência de Alimentos, Faculdade de Engenharia de Alimentos, \\ Universidade Estadual de Campinas, CP 6121, 13083-970 Campinas-SP, Brazil \\ ${ }^{b}$ Centro Pluridisciplinar de Pesquisas Químicas, Biológicas e Agrícolas, \\ Universidade Estadual de Campinas, CP 6171, 13081-970 Campinas-SP, Brazil \\ ${ }^{c}$ Departamento de Fisiologia, Instituto de Biologia, Universidade Estadual de Campinas, \\ CP 6109, 13081-970 Campinas-SP, Brazil
}

\begin{abstract}
Ratos Wistar machos foram expostos por via oral, durante 28 dias, a 1/10 do valor da DL50 (concentração letal) da permetrina (PMT) ou deltametrina (DMT). O objetivo deste estudo foi determinar os resíduos de PMT e DMT no fígado e coração dos ratos ao final do período de exposição e avaliar o efeito nos níveis de resíduos devido à ingestão de pectina e celulose na dieta. Os analitos foram extraídos em acetonitrila e a limpeza dos extratos foi realizada por extração em fase sólida com florisil antes da análise por GC-ECD (cromatografia gasosa com captura de elétrons). Para PMT, os limites de quantificação (LOQ) foram 1,0 e 0,2 $\mu \mathrm{g} \mathrm{g}^{-1}$ e para DMT 0,9 e $0,2 \mu \mathrm{g} \mathrm{g}^{-1}$ para fígado e coração, respectivamente. Não foi verificada a presença de resíduos de PMT ou DMT acima do LOQ do método, tanto no fígado como no coração dos animais expostos.
\end{abstract}

For 28 days male Wistar rats were submitted to oral exposure with 1/10 of the LD50 value of permethrin (PMT) or deltamethrin (DMT). The aim of this study was to determine the residues of PMT and DMT in the liver and heart of the rats at the end of the exposure period, as well as to evaluate the effect of ingesting pectin and cellulose via the diet. The analytes were extracted with acetonitrile and the extracts were cleaned up by solid phase extraction with florisil before GC-ECD (gas chromatography coupled with an electron-capture detector) analysis. For PMT, the limits of quantitation (LOQ) were 1.0 and $0.2 \mu \mathrm{g} \mathrm{g}^{-1}$ and for DMT 0.9 and $0.2 \mu \mathrm{g} \mathrm{g}^{-1}$ for liver and heart, respectively. No PMT or DMT residues were verified above the LOQ of the method in either the liver or heart of the exposed animals.

Keywords: permethrin, deltamethrin, pyrethroids, insecticide residues, subchronic toxicity

\section{Introduction}

Pyrethroid pesticides are used in agriculture to control insects in vegetables, fruits and field crops, in public health to control diseases caused by vectors, and as a veterinary drug against ectoparasites. These agents do not persist in the environment and tend to exhibit slow development of insect resistance. ${ }^{1}$ In general, pyrethroids are more effective against a wider range of insect pests and furthermore have a much lower mammal-to-insect toxicity ratio than their organochlorine, organophosphate and carbamate counterparts. ${ }^{2}$ Nevertheless, the widespread use of these

*e-mail: marili@cpqba.unicamp.br insecticides has lead to an increased exposure of workers and the ecosystem, ${ }^{3}$ increasing the possibility of their entering the food chain via the meat or via their residues in fruits, vegetables and water. ${ }^{4,5}$

The acute neurotoxicity of pyrethroids has been well characterized in several reviews. ${ }^{1,6,7}$ However, although cardiovascular manifestations frequently accompany exposure to these compounds, their cardiotoxicity appears to have been little studied. ${ }^{8,9}$ On the other hand, histological changes and alterations in the biochemical parameters were reported in rats after a single oral exposure to $\alpha$-cypermethrin, ${ }^{10}$ and residual concentrations of deltamethrin were found in several rat tissues after repeated oral exposure to the pyrethroid, with the maximum level in 
the lung..$^{11}$ Although the pyrethroids are not easily absorbed through the skin, they are well absorbed through the gut and pulmonary membrane. ${ }^{12}$ In this context, the determination of residual levels of pyrethroids in target tissues contributes to an understanding of the toxicity of these compounds on the target tissue.

It has been reported that supplementation of the diet with dietary fibers can decrease the toxicity caused by food carcinogens and organophosphorus pesticides. ${ }^{13}$ Dietary fiber may decrease the absorption of pesticides from the gastrointestinal tract (GIT), and the binding of pesticides to the fibers is determined by the nature and level of the fiber. ${ }^{13}$ Also various organic and inorganic chemicals are possibly bound to dietary fiber in the GIT and quickly excreted in the stools. ${ }^{14,15}$

Generally the residual pyrethroid levels in different matrices are determined using chromatographic methods, mainly gas chromatography with electron-capture ${ }^{5}$ (GC-ECD) or mass spectrometry detection (GC-MS), ${ }^{16-18}$ and liquid chromatography has also been employed in some studies. ${ }^{19,20}$ Nevertheless electron-capture detection (ECD) is the most frequently selected system for the determination of pyrethroid residues, being especially suitable for the determination of those pyrethroids which possess a chloro atom (cypermethrin, permethrin), bromo atom (deltamethrin), fluoro atom (cyhalothrin), or chloro and fluoro atoms (fluvalinate) in their structure. For biological tissues, GC-ECD was recently used to determine pyrethroid residues in bovine fat, ${ }^{5}$ as well as in the liver, brain, testis, kidney, lungs and heart of rats. ${ }^{11}$

With respect to sample preparation, several methods have been developed including liquid-liquid extraction (LLE), solid-phase extraction (SPE) $)^{21,22}$ matrix solid-phase dispersion (MSPD) $)^{23}$ and solid-phase microextraction (SPME), as alternative analytical techniques for some matrixes. ${ }^{24}$ Evidently, the clean-up technique to be used will depend on the matrix under study.

Since there is little data on the residual levels of pyrethroids in heart tissue after sub-chronic oral exposure to these compounds and previous studies carried out in the author's laboratory showed cardiotoxic effects in rats after the repeated daily oral administration of PMT and $\mathrm{DMT}^{25}$ (Figure 1), the aim of this study was to determine the residual levels of PMT and DMT in the liver and heart

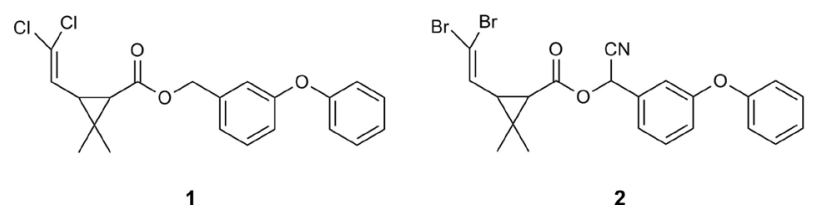

Figure 1. Chemical structures of permethrin (1) and deltamethrin (2). tissues of Wistar rats submitted to sub-chronic oral exposure (28 days) with pyrethroids. Also, since the presence of pectin in the diet showed a protective effect against the cardiotoxicity ${ }^{25}$ and hepatotoxicity ${ }^{26}$ of PMT and DMT, the effect of ingesting pectin and cellulose on the residual levels of the pyrethroids was also evaluated.

\section{Experimental}

\section{Chemicals}

The analytical standard of deltamethrin (DMT) (99\% purity) was obtained from Chem Service (West Chester, PA, USA), permethrin (PMT) (98\% purity) and cypermethrin (CMT) (92\% purity, used as the internal standard) were purchased from Sigma-Aldrich (Seelze, Germany). DMT ( $90.2 \%$ purity) provided by Bayer CropScience (São Paulo, Brazil) and PMT (97.4\% purity) donated by FMC Química do Brasil Ltda. (São Paulo, Brazil), were used in the biological assays. HPLC-grade solvents (acetonitrile, methanol, hexane and ethyl acetate) were obtained from Fisher Scientific (Fair Lawn, New Jersey, USA). Anhydrous reagent grade sodium sulfate and florisil (60-100 mesh) were obtained from Merck (Darmstadt, Germany). Microcel (cellulose, type 3E-200) was kindly donated by Blanver Farmoquímica Ltda. (Itapevi, SP, Brazil) and pectin was purchased from CP Kelco S.A. (Limeira, SP, Brazil).

\section{Biological assay}

Male, 4-week-old Wistar rats, free of pathogenic agents (SPF) were obtained from the Multidisciplinary Center for Biological Research (CEMIB) of the University of Campinas (UNICAMP) (Campinas-SP, Brazil). The protocol of the assay was approved by the UNICAMP Institutional Committee for Ethics in Animal Research (Protocol 721-2), which follows the recommendations of the Guide for the Care and Use of Laboratory Animals.

The animals were housed in individual cages under conditions of controlled temperature $\left(22 \pm 2^{\circ} \mathrm{C}\right)$, humidity (60-70\%) and artificial lighting (12 h light / $12 \mathrm{~h}$ dark, lights on at 7.00 a.m.), with free access to commercial feed (Labina, Purina ${ }^{\circledR}$, Paulínia-SP, Brazil) and water. They were randomly selected and maintained under adaptation for a period of 7 days before beginning the experiments.

The experimental groups received a dose of PMT or DMT corresponding to $1 / 10$ of the LD50 value of the pyrethroid. For this purpose, the body mass of the individual rats was recorded every two days and the pyrethroid solutions remade accordingly. The test substances (PMT and DMT) were suitably diluted with commercial corn oil 
Table 1. Treatments used in the biological assay

\begin{tabular}{|c|c|c|c|c|c|c|c|}
\hline \multirow[t]{2}{*}{ Commercial diet } & \multicolumn{7}{|c|}{ Groups } \\
\hline & $\mathrm{I}^{*}$ & II & III & IV & $\mathrm{V}$ & VI & VII \\
\hline Corn oil & $\times$ & & & & & & \\
\hline PMT (47.1 $\mathrm{mg} \mathrm{kg}^{-1}$ b.w. per day) & & $x$ & & $\times$ & $\times$ & & \\
\hline DMT (1.1 $\mathrm{mg} \mathrm{kg}^{-1}$ b.w. per day) & & & $x$ & & & $x$ & $x$ \\
\hline Pectin $5 \%(\mathrm{~m} / \mathrm{m})$ & & & & $x$ & & $\times$ & \\
\hline Cellulose $5 \%(\mathrm{~m} / \mathrm{m})$ & & & & & $x$ & & $x$ \\
\hline
\end{tabular}

(*) control

and orally administered $(5 \mathrm{~mL})$ daily by gavage as a single dose for 28 days. The dietary fiber (pectin or cellulose) was added to the commercial feed at a level of $5 \%(\mathrm{~m} / \mathrm{m})$. In addition, the commercial diet already contained $5 \%(\mathrm{~m} / \mathrm{m})$ of cellulose in its formulation. The animals were sacrificed $24 \mathrm{~h}$ after administration of the last dose of the pyrethroid, and the liver and heart removed. The treatments used are described in Table 1.

\section{Analytical assay}

\section{Chromatographic system and conditions}

A Varian GC series 3400 (Varian, USA) equipped with an electron capture detector and a HP-5MS $30 \mathrm{~m} \times 0.53 \mathrm{~mm} \times 2.65 \mu \mathrm{m}$ megabore column (Hewlett Packard, USA) was used. The injector and detector temperatures were $270{ }^{\circ} \mathrm{C}$ and $300{ }^{\circ} \mathrm{C}$, respectively. The nitrogen carrier gas rate was $10 \mathrm{~mL} \mathrm{~min}^{-1}$ and the makeup $20 \mathrm{~mL} \mathrm{~min}^{-1}$. The column temperature program was as follows: initial $250{ }^{\circ} \mathrm{C}\left(3{ }^{\circ} \mathrm{C} \mathrm{min}-1\right)$ to $270{ }^{\circ} \mathrm{C}$ and hold for $30 \mathrm{~min}$. The injection volume was $1 \mu \mathrm{L}$.

\section{Standard solutions}

Stock solutions $\left(600 \mu \mathrm{g} \mathrm{mL} \mathrm{mL}^{-1}\right)$ of each pyrethroid reference standard were prepared by dissolving $12.0 \mathrm{mg}$ in $25 \mathrm{~mL}$ of acetonitrile. Working standard solutions containing both pyrethroids at a concentration of $24 \mu \mathrm{g} \mathrm{mL}-1$ were prepared daily by dilution of the stock solutions in acetonitrile and used to spike the blank liver and heart samples. The internal standard solution of cypermethrin $\left(80 \mu \mathrm{g} \mathrm{mL}^{-1}\right)$ was prepared in acetonitrile.

\section{Analytical curves}

Liver. The analytical curves for the PMT and DMT in the rat liver were prepared by spiking $2.00 \mathrm{~g}$ of the blank homogenized (Ultra-Turrax system, IKA) liver sample with $100,200,400,600$ and $800 \mu \mathrm{L}$ of the working standard solution and $10 \mu \mathrm{L}$ of the cypermethrin internal standard solution. All the spiked liver samples were then extracted using the extraction procedure described below.
Heart. The analytical curves for the PMT and DMT in the rat heart were prepared by spiking $1.00 \mathrm{~g}$ of the whole blank homogenized (Ultra-Turrax system, IKA) heart sample (weighing approximately $1.0 \mathrm{~g}$ ) with 10, 20, 30, 40 and $50 \mu \mathrm{L}$ of the working standard solution and $10 \mu \mathrm{L}$ of the cypermethrin internal standard solution. All the spiked heart samples were then extracted using the extraction procedure described below.

\section{Extraction procedure}

Liver. Using a $50 \mathrm{~mL}$ centrifuge tube, $2.00 \mathrm{~g}$ of triturated rat liver, $10 \mu \mathrm{L}$ of cypermethrin internal standard solution and $15 \mathrm{~mL}$ of acetonitrile were combined and extracted twice in an Ultra-Turrax system for $1 \mathrm{~min}$. The extracts were combined and centrifuged at $9000 \mathrm{~g}$ for $6 \mathrm{~min}$. The supernatant was dried using a Fisaton vacuum evaporator (São Paulo, Brazil), and the residue suspended in $5 \mathrm{~mL}$ of hexane and applied to a preconditioned florisil column. The column $(75 \times 13 \mathrm{~mm})$ was prepared by packing it, successively, with $1.0 \mathrm{~g}$ florisil (60-100 mesh) and $2.5 \mathrm{~g}$ of anhydrous sodium sulfate. The packed florisil column was fitted onto a SPE Alltech vacuum manifold (Deerfield, IL, USA), conditioned with $6 \mathrm{~mL}$ hexane and not allowed to dry. The sample extract was applied to the column and the analytes eluted with $15 \mathrm{~mL}$ hexane-ethyl acetate $(95: 5 \mathrm{v} / \mathrm{v})$. The eluate was concentrated to dryness under vacuum and diluted with methanol to a volume of $5.0 \mathrm{~mL}$. A $1 \mu \mathrm{L}$ volume was injected manually into the GC-ECD.

Heart. Using a $15 \mathrm{~mL}$ centrifuge tube, the whole rat heart (weighing approximately $1.0 \mathrm{~g}$ ), $10 \mu \mathrm{L}$ of cypermethrin internal standard solution and $5 \mathrm{~mL}$ of acetonitrile were combined and extracted twice in an Ultra-Turrax system for $1 \mathrm{~min}$. The extracts were combined and centrifuged at $9000 \mathrm{~g}$ for $6 \mathrm{~min}$. The supernatant was dried in a vacuum evaporator and the residue suspended in $5 \mathrm{~mL}$ of hexane and applied to a preconditioned florisil column. The sample extract was applied to the column and the analytes eluted with $15 \mathrm{~mL}$ hexane-ethyl acetate $(95: 5 \mathrm{v} / \mathrm{v})$. The eluate was concentrated almost to dryness under vacuum and diluted 
with methanol to a volume of $1.0 \mathrm{~mL}$. A $1 \mu \mathrm{L}$ volume was injected manually into the GC-ECD.

\section{Method validation}

The method was in-house validated using the following performance criteria: linear range and linearity, sensitivity, precision, accuracy and the detection and quantitation limits.

The linearity and sensitivity were established by way of the analytical curve obtained by duplicate analyses at five concentration levels for each pyrethroid (DMT and PMT), and prepared by spiking blank samples of each matrix before extraction. A fixed amount (800 ng) of internal standard (cypermethrin) was added to all samples. The linearity and sensitivity were expressed as the correlation coefficient (r) and the slope of the analytical curve, respectively. The limits of detection (LOD) and quantitation (LOQ) were experimentally established from the signal-noise ratios of $3: 1$ and 10:1, respectively. The precision of the method, expressed as the relative standard deviation of the peak area measurements, was obtained using the analysis of six independent samples of each matrix (liver and heart) with $0.94 \mu \mathrm{g} \mathrm{g}^{-1}$ PMT and $0.72 \mu \mathrm{g} \mathrm{g}^{-1}$ DMT. The accuracy of the method was evaluated by way of a recovery test, analyzing samples (liver and heart) spiked with PMT and DMT at two different fortification levels, and determined as the percent recovery. The response of the pyrethroids was expressed as "sum of isomers" for PMT, DMT and CMT.

\section{Results and Discussion}

\section{Analytical method}

To solve the problems resulting from the complexity and lipophilicity of the matrix studied (liver and heart) a
SPE technique was chosen. The polar nature of synthetic magnesium silicate (Florisil) was suitable for the clean-up of the matrix extracts, thus retaining the lipid fraction on elution with low polarity organic solvents.

The method was in-house validated for the quantitation of PMT and DMT in the liver and heart of Wistar rats. The validation data are summarized in Table 2.

The correlation coefficient, linear range and sensitivity were obtained from analytical curves at five concentration levels for the PMT and DMT in the liver and heart, with duplicate analyses and using an internal standard (CMT). The linearity was tested using a pure error lack of fit test with simple regression, which was not significant at the 5\% level for PMT and DMT in either of the matrices studied.

The precision and accuracy of the method for PMT and DMT were evaluated using six determinations at the LOQ value and above. The results of precision, expressed as coefficient of variation $(\mathrm{CV})$ varied from 5.1 to $14 \%$ for higher fortification levels and, the $\mathrm{CV}$ values obtained showed the greatest variation (13-24\%) near the LOQ, as expected since precision is generally dependent on the analyte concentration. However, the $\mathrm{CV}$ values obtained are within or close to the estimated values obtained from the Horwitz equation. ${ }^{27}$

The limit of detection (LOD) represents the lowest estimated concentration of an analyte in a sample that can be detected by the method, and the LOQ represents the lowest value that can be determined reliably in the matrix with precision and accuracy. Unfortunately, the present validation results cannot be compared with data in the literature, since validated analytical methods for the determination of pyrethroids in liver and heart are scarce. For instance, in one available study that reports on deltamethrin residues in several tissues, including liver and

Table 2. Validation parameters for the gas chromatography-electron capture detection (GC-ECD) method used to determine permethrin and deltamethrin in the liver and heart of rats

\begin{tabular}{|c|c|c|c|c|}
\hline \multirow{2}{*}{ Validation Parameters } & \multicolumn{2}{|c|}{ Permethrin } & \multicolumn{2}{|c|}{ Deltamethrin } \\
\hline & Liver & Heart & Liver & Heart \\
\hline Linear range $\left(\mu \mathrm{g} \mathrm{g}^{-1}\right)$ & $1.18-9.41$ & $0.24-1.18$ & $0.90-7.22$ & $0.18-0.90$ \\
\hline Linearity (r) & 0.9970 & 0.9995 & 0.9985 & 0.9994 \\
\hline Sensitivity (AU $\mu \mathrm{g}^{-1} \mathrm{~g}$ ) & 0.2737 & 0.2222 & 1.0916 & 1.386 \\
\hline $\operatorname{LOD}\left(\mu \mathrm{g} \mathrm{g}^{-1}\right)$ & 0.7 & 0.1 & 0.5 & 0.1 \\
\hline LOQ $\left(\mu g g^{-1}\right)$ & 1.0 & 0.2 & 0.9 & 0.2 \\
\hline $\begin{array}{l}\text { Precision, CV \% } \\
\text { (fortification level) }\end{array}$ & $\begin{array}{c}8.8 \\
\left(4.7 \mu \mathrm{g} \mathrm{g}^{-1}\right)\end{array}$ & $\begin{array}{c}9.5 \\
\left(2.4 \mu \mathrm{g} \mathrm{g}^{-1}\right)\end{array}$ & $\begin{array}{c}5.1 \\
\left(3.6 \mu \mathrm{g} \mathrm{g}^{-1}\right)\end{array}$ & $\begin{array}{c}14 \\
\left(1.8 \mu \mathrm{g} \mathrm{g}^{-1}\right)\end{array}$ \\
\hline $\mathrm{n}=6$ & $\begin{array}{c}20 \\
\left(1.2 \mu \mathrm{g} \mathrm{g}^{-1}\right)\end{array}$ & $\begin{array}{c}13 \\
\left(0.24 \mu \mathrm{g} \mathrm{g}^{-1}\right)\end{array}$ & $\begin{array}{c}24 \\
\left(0.90 \mu \mathrm{g} \mathrm{g}^{-1}\right)\end{array}$ & $\begin{array}{c}20 \\
\left(0.18 \mu \mathrm{g} \mathrm{g}^{-1}\right)\end{array}$ \\
\hline $\begin{array}{l}\text { Accuracy, recovery \% } \\
\text { (fortification level) } \\
\mathrm{n}=6\end{array}$ & $\begin{array}{c}99.0 \\
\left(4.7 \mu \mathrm{g} \mathrm{g}^{-1}\right) \\
103 \\
\left(1.2 \mu \mathrm{g} \mathrm{g}^{-1}\right)\end{array}$ & $\begin{array}{c}102 \\
\left(2.4 \mu \mathrm{g} \mathrm{g}^{-1}\right) \\
102 \\
\left(0.24 \mu \mathrm{g} \mathrm{g}^{-1}\right)\end{array}$ & $\begin{array}{c}97.7 \\
\left(3.6 \mu \mathrm{g} \mathrm{g}^{-1}\right) \\
105 \\
\left(0.90 \mu \mathrm{g} \mathrm{g}^{-1}\right)\end{array}$ & $\begin{array}{c}99.5 \\
\left(1.8 \mu \mathrm{g} \mathrm{g}^{-1}\right) \\
97.3 \\
\left(0.18 \mu \mathrm{g} \mathrm{g}^{-1}\right)\end{array}$ \\
\hline
\end{tabular}

CV: coefficient of variation. 
heart, and using a GC-ECD method, the validation data were not reported. ${ }^{11}$

Typical chromatograms of the heart and liver samples are shown in Figures 2A and 2B. The considerable amount of interference present in these matrixes, especially in the liver, did not allow for lower LOD and LOQ values to be obtained in the analytical GC-ECD method used. Nevertheless, according to Akre and $\mathrm{MacNeil}^{5}$ eight synthetic pyrethroids were determined in bovine fat by GC-ECD with a limit of quantitation (LOQ) range from 25 to $50 \mu \mathrm{g} \mathrm{kg}^{-1}$. These LOQ values were lower than in the present study, probably due to differences in the matrices. Furthermore, the LOD and LOQ values reported by Kim et $a l .{ }^{20}$ for deltamethrin in plasma, liver, kidney and brain using HPLC-DAD (high-performance liquid chromatography with diode array) at $230 \mathrm{~nm}$ were 0.01 and $0.05 \mu \mathrm{g} \mathrm{mL}{ }^{-1}$, respectively. Although, these authors reported the LOD and LOQ values for liver, their values cannot be compared with the present results, since the unit used by the investigators to report their results $\left(\mu \mathrm{g} \mathrm{mL}^{-1}\right)$ was not equivalent to that used in the present study $\left(\mu \mathrm{g} \mathrm{g}^{-1}\right)$.

Figure 2 shows the chromatograms of the extracts from the heart and liver (blank and spiked samples) obtained using the optimized GC-ECD conditions.

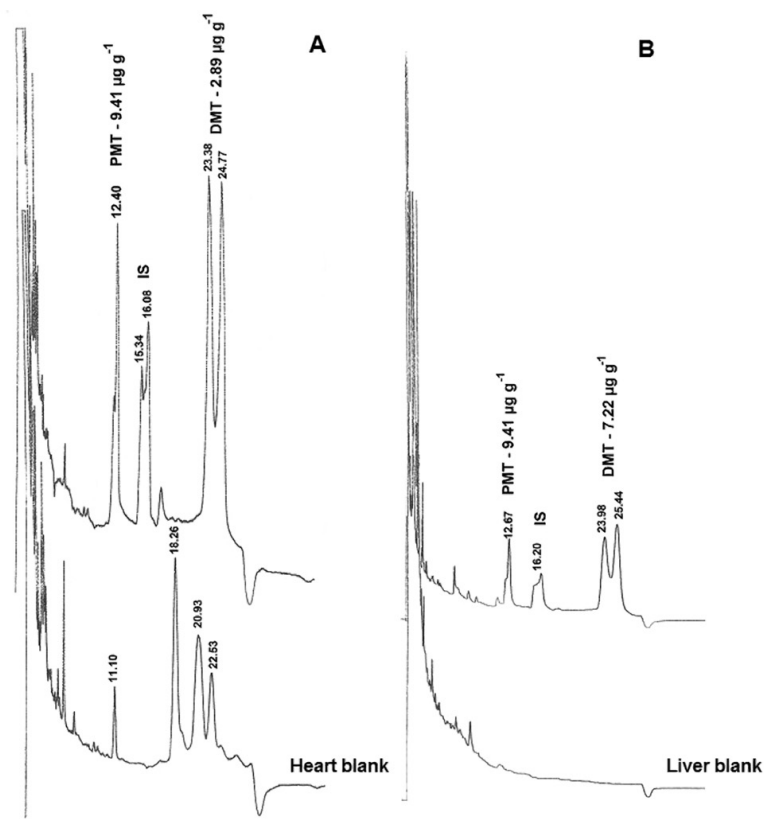

Figure 2. Chromatograms obtained by gas chromatography-electron capture detection (GC-ECD) of blank and spiked samples of heart (A) and liver (B). Cypermethrin was used as the internal standard (IS).

\section{Residue level of pyrethroids}

The validated analytical method was used to determine the PMT and DMT residues in the liver and heart of the rats orally exposed every day to the pyrethroids, with or without dietary fiber added to the diet. It has been reported that permethrin ${ }^{28}$ and deltamethrin ${ }^{29}$ are rapidly absorbed, distributed and excreted by rats after oral administration, with a low potential for accumulation. In addition, it has been reported that residues of pyrethroids in tissues are generally quite low. ${ }^{30}$ In the case of permethrin, repeated exposure resulted in temporary accumulation in the fat tissue, but the chemical dissipated rapidly once exposure ceased. ${ }^{28}$ Deltamethrin is rapidly absorbed by the gastrointestinal tract when administered orally, and rapidly bio-transformed in the liver of the mammals through oxidation reactions and ester cleavage. The initial detoxification reaction is the cleavage of the ester bond, probably by esterases, or a reaction catalyzed by cytochrome P-450 and subsequent conjugation. ${ }^{31}$ It has been reported that the rate of deltamethrin metabolism is 8 times higher in liver than in plasma. ${ }^{32}$ However, Manna et al. ${ }^{11}$ reported residues of deltamethrin in liver $\left(0.92 \pm 0.01 \mu \mathrm{g} \mathrm{g}^{-1}\right)$, heart $\left(0.15 \pm 0.02 \mu \mathrm{g} \mathrm{g}^{-1}\right)$, brain $\left(0.74 \pm 0.05 \mu \mathrm{g} \mathrm{g}^{-1}\right)$, testis $\left(0.10 \pm 0.01 \mu \mathrm{g} \mathrm{g}^{-1}\right)$, kidney $\left(0.09 \pm 0.01 \mu \mathrm{g} \mathrm{g}^{-1}\right)$ and lungs $\left(3.00 \pm 0.12 \mu \mathrm{g} \mathrm{g}^{-1}\right)$ after 30 days of oral exposure.

Although residues of $\alpha$-cypermethrin have been reported in different tissues, including in the liver and heart, ${ }^{11,19}$ in the present study no detectable residues of PMT or DMT were verified in either tissue, even at the LOD of the method, and even considering the cardiotoxicity effects reported as a consequence of oral exposure to PMT or DMT. ${ }^{25,26}$ These results provide evidence that PMT and DMT induce physiological effects in the heart muscle at tissue levels below the LOQ of the method. This also corroborates with the idea that PMT and DMT are rapidly metabolized and do not accumulate in the liver and heart of exposed rats, probably due to the rapid metabolism of these compounds. ${ }^{18,28,29}$ Additional studies are necessary to elucidate the dose-effect relationship for the cardiotoxicity of the pyrethroids.

It is known that the binding capacity of dietary fibers to xenobiotics reduces the toxicity, since no residues of the pyrethroids were found in the liver or heart, even in the absence of added cellulose and pectin to the diet. The protective effect of these dietary fibers could not be corroborated in the present study. Purified fiber sources were used in order to avoid possible interference from constituents that are naturally present in the whole fiber from raw sources.

\section{Conclusions}

The method used was effective in determining the residual levels of the pyrethroids in the tissues. However, 
oral subchronic exposure of rats to permethrin and deltamethrin at a dose equivalent to $1 / 10$ of the $\mathrm{LD}_{50}$ value did not result in residues in the liver or heart, with or without added pectin and cellulose to the diet. The results demonstrated that the dose used was not sufficient to accumulate residues of permethrin and deltamethrin in the liver of the animals, and/or this organ was efficient in bio-transforming and excreting the pyrethroids. No residues of the pyrethroids were detected in the heart either. Taking into consideration the reported cardiotoxicity of the pyrethoids, the present results suggest that PMT and DMT act morphologically in the heart, mainly with respect to its electric function, even at a level lower than the LOQ value established in this study.

\section{Acknowledgments}

The authors gratefully acknowledge the financial support from $\mathrm{CNPq}$ and CAPES, and thank Professor Hilary Castle de Menezes for language assistance.

\section{References}

1. Soderlund, D. M.; Clark, J. M.; Sheets, L. P.; Mullin, L. S.; Piccirillo, V. J.; Sargent, D.; Stevens, J. T.; Weiner, M. L.; Toxicology 2002, 171, 3.

2. León-González, M. E.; Plaza-Arroyo, M.; Pérez-Arribas, L. V.; Polo-Díez, L. M.; Anal. Bioanal. Chem. 2005, 382, 527.

3. Viran, R.; Erkoç, F. U.; Polat, H.; Koçak, O.; Ecotox. Environ. Safe 2003, 55, 82.

4. Kumari, B.; Madan, V. K.; Kathpal, T. S.; Environ. Monit. Assess. 2006, 123, 407.

5. Akre, C. J.; MacNeil, J. D.; J. AOAC Int. 2006, 89, 1425.

6. Narahashi, T.; Pharmacol. Toxicol. 1996, 79, 1.

7. Valentine, W. M.; Vet. Clin. N. Am.-Small 1990, 20, 375.

8. Spencer, C. L.; Yuill, K. H.; Borg, J. J.; Hancox, J. C.; Kozlowski, R. Z.; J. Pharmacol. Exp. Ther. 2001, 298, 1067.

9. De La Cerda, E.; Navarro-Polanco, R. A.; Sánchez-Chapula, J. A.; Arch. Med. Res. 2002, 33, 448.

10. Manna, S.; Bhattacharyya, D.; Bassak, D. K.; Mandal, T. K.; Indian J. Pharmacol. 2004, 36, 25.

11. Manna, S.; Bhattacharyya, D.; Mandal, T. K.; Das, S.; Indian J. Pharmacol. 2005, 37, 160.

12. Available: www.beyondpesticides.org accessed in October 2008.
13. Ta, C. A.; Zee, J. A.; Desrosiers, T.; Marin, J.; Lavallois, P.; Ayote, P.; Poirier, G.; Food Chem. Toxicol. 1999, 37, 1147.

14. Ikegami, S.; Umegaki, K.; Kawashima, Y.; Ichikawa, T.; J. Nutr. 1994, 124, 754.

15. Sera, N.; Morita, K.; Nagasoe, M.; Tokieda, H.; Kitaura, T.; Tokiwa, H.; J. Nutr. Biochem. 2005, 16, 50.

16. Ramesh, A.; Ravi, P. E.; J. Chromatogr. B 2004, 802, 371.

17. Beltran, J.; Peruga, A.; Pitarch, E.; López, F. J.; Hernández, F.; Anal. Bioanal. Chem. 2003, 376, 502.

18. Leng, G.; Gries, W.; J. Chromatogr. B 2005, 814, 285.

19. Ding, Y.; White, C. A.; Muralidhara, S.; Brucker, J. V.; Barlett, M. G.; J. Chromatogr. B 2004, 810, 221.

20. Kim, K. B.; Bartlett, M. G.; Anand, S. S.; Bruckner, J. V.; Kim, H. J.; J. Chromatogr. B 2006, 834, 141.

21. Chen, Z. M.; Wang, Y. H.; J. Chromatogr. A 1996, 754, 367.

22. Barrionuevo, W. R.; Lanças, F. M.; Bull. Environ. Contam. Toxicol. 2002, 69, 123.

23. Di Muccio, A.; Pelosi, P.; Barbini, D. A.; Generali, T.; Girolimetti, T.; Stefanelli, P.; Leonelli, A.; Amendola, G.; Vergori, L.; Fresquet, E. V.; J. Chromatogr. A 1999, 833, 19.

24. Fernandez-Alvarez, M.; Llompart, M.; Lamas, J. P.; Lores, M.; Garcia-Jares, C.; Cela, R.; Dagnac, T.; Anal. Chim. Acta 2008, $617,37$.

25. Santos, M. A. T.; Areas, M. A.; Reyes, F. G. R.; Toxicol. Lett. 2006, 164S, S240.

26. Santos, M. A. T.; Areas, M. A.; Reyes, F. G. R.; Toxicol. Lett. 2006, 164S, S240, S241.

27. Harris, D. C.; Análise Química Quantitativa, 6a. ed., LTC Editora: Rio de Janeiro, Brasil, 2005, chapter 29.

28. Available: www.inchem.org/documents/jmpr/jmpmono/ v00pr04.htm accessed in April 2010.

29. Available: www.inchem.org/documents/jmpr/jmpmono/ v99pr07.htm accessed in April 2010.

30. Shiba, K.; Kakuta, N.; Kaneko, H.; Nakatsuka, I.; Yoshiake, A.; Yamada, H.; Miyamoto, J.; J. Pestic. Sci. 1988, 13, 557.

31. Hieder, A. F.; Hirsch-Ernst, K. I.; Bauer, D.; Kahl, G. F.; Desel, H.; Biochem. Pharmacol. 2001, 62, 71.

32. Anand, S. S.; Bruckner, J. V.; Haines, W. T.; Muralidhara, S., Fisher, J. W.; Padilla, S.; Toxicol. Appl. Pharmacol. 2006, 212 , 156.

Submitted: June 24, 2010

Published online: February 1, 2011

FAPESP has sponsored the publication of this article. 